\title{
R Research S Surare \\ Functional and Healthy Properties of Yoghurt adding to Green Tea and Coffee Extracts on Reducing Obese and its Complications in Rats
}

hanan shalaby ( $\nabla$ shalabyhanan31@yahoo.com )

Zagazig University Faculty of Agriculture https://orcid.org/0000-0002-3861-6420

Yousif Elhassaneen

Minoufiya University: Menoufia University

\section{Research Article}

Keywords: Antioxidant activities, obesity, lipids profile, liver and kidney functions, green tea and green coffee beans

Posted Date: March 16th, 2021

DOI: https://doi.org/10.21203/rs.3.rs-293107/v1

License: (c) (i) This work is licensed under a Creative Commons Attribution 4.0 International License.

Read Full License 


\section{Abstract}

The chemical composition and sensory evaluation of yoghurt adding to green tea (GTE) and coffee (GCE) extracts on obese rats were investigated. Ethanol extracts were prepared from green tea and green coffee and their total phenolic compounds and identified phenolic compounds were evaluated. Results showed that the GTE and GCE have highly antioxidant activities. Yoghurt was prepared from low fat buffalo's milk ( $1.5 \%$ fat) blended with $1 \%$ of GTE or GCE. Addition of GTE or GCE had no significant effects on the chemical composition and sensory evaluation. Higher sensory scores were reported flavor for GTE and GCE yoghurt than control. It was also noticed that addition of GTE or GCE to yoghurt increased viscosity a key defensive effect on the gel-factors. Feeding of obese rats on yoghurt adding to GTE or GCE showed that significant differences low of weight compared to positive group. There were no significant differences of heart weights tissue while, kidney and liver weights tissues were significant differences. Also, fed obese rats on yoghurt supplemented with GTE or GCE decreased the lipids profile comparative with positive control group and improvement of liver and kidney functions. The best treatment was observed in yoghurt adding to green coffee beans extract which had lowest value of liver and kidney function parameters followed by yoghurt adding to green tea extract. The histopathological examination observed normalized in the groups fed yoghurt supplemented green tea and coffee beans extracts. According to this study, when added to green tea and coffee beans extracts could be increased the useful health effects of yogurt by intensifying antioxidant activity. Yoghurt adding to GTE or GCE had therapeutic effects on obese rats. Also improve the liver and kidney functions.

\section{Highlights}

1. The study provides first data about chemical composition and sensory evaluation of yoghurt adding to green tea (GTE) and coffee (GCE) extracts on obese rats.

2. This study is the first that evaluates total phenolic compounds and identified phenolic compounds.

3. Fed obese rats on yoghurt supplemented with GTE or GCE decreased the lipids profile were low values of obesity.

4. Our results show that yoghurt supplemented with GTE or GCE can be used healthy food.

\section{Introduction}

Obesity can be a large health problem in the world and probability more than 500 million adults were obese in 2008 (Chen et.al., 2014). Obesity problems can have a harmful effect of move on years and decrease in life expectancy. There are a lot of selection for cure of obesity which containing training, diet and, health cure for weight loss (Nagham and Alhamhany 2018).

Yogurt consider of fermented dairy products in the world by fermentation with lactic acid bacteria. Yoghurt one of the majorities generally consumed (Change et.al., 2018). The second drinking water on the earth is green tea that high containing of antioxidant (Chiu 2006). Green tea and coffee drinking are widely all the rage international. Coffee consumption due to reduce hunger and other components have 
protecting effects on more diseases such as Alzheimer's (Cao et. al.,2011). The eating of coffee and tea reduced the danger of obesity especially among women and they might be considered as a functional food (Dórea et. al.,2005). Based on this health eating recommendation by Canadian government's Guildline., drinking of 3 cups of brewed caffeinated coffee (400-450 mg caffeine) is safe (Health Canada Food Program 2006). Coffee and green tea are the majority usual drinking beverages in the earth which have several benefit components. Coffee and green tea have significantly converse connection with obesity, diabetes, and cardiovascular diseases (Izadi1 et.al., 2018).

Several experimental, were presented concerning the effects of coffee on health and prevention of chronic diseases. Coffee have many components including caffeine, phenolic acid, and antioxidants display the defending roles on obesity, diabetes, and inflammation (Rebelloet. al., 2011and Yamashita et al. 2012). Green tea extracts have several naturally moving natural value of polyphenolic epicatechins (Jae, et.al., 2014). Photochemical had a potential avoidance of some chronic disorders metabolic diseases that including obesity and insulin health benefits through that natural bioactive have beneficial effects healthy (Meydani and Hasan 2010). Coffee extract could be improving the useful properties of milk or yoghurt and possible therapeutic importance increase (Marhamatizadeh et. al., 2014). Mechanism for obesity administration, including green tea and caffeine could be planned as strategy for weight defeat and might raise calories split and probable to neutralize the reduce in metabolic speed (Kristel et. al., 2006). The consumption of green tea and coffee have anticancer such as breast, lung and blood cancers (Sumioet al., (2020).

Therefore, the present study was carried out to investigate the effects of feeding yoghurt adding to green tea and coffee extracts on obesity and its $\mathrm{c}$ rats complications.

\section{Materials And Methods}

\section{Materials}

Green tea (Camellia sinensis) leaves and green coffee beans (Coffearobusta)were obtained from local market of Zagazig, Egypt and dried in an air-drying oven $\left(40^{\circ} \mathrm{C}\right)$. Total cholesterol kits, triglyceride and total high -density lipoprotein cholesterol (HDL-C), and another kits were purchased form Sigma-Aldrich (MO, IL USA).

\section{Milk}

Fresh buffalo's milk (1.5\% fat) was obtained from Dairy Technology Unit, Food Science Department, Faculty Agric., Zagazig.Univ.

\section{Starter Cultures}

Yoghurt culture supplemented Streptococcus salivarius subsp. thermophilus EMCC104 and Lactobacillus delbruekii subsp. bulgaricus EMCC1102 were obtained from the Microbiological Resources Center 
(MIRCEN), Faculty of Agric.,Ain Shams Univ., Egypt.

\section{Methods}

\section{Preparation of green tea and green coffee extracts (GTE and GCE)}

Green tea and green coffee beans were extracted with ethanol $(80 \%)$, at a ratio of 1:10 $(\mathrm{w} / \mathrm{v})$ in closed vessels by stirring at room temperature $\left(25^{\circ} \mathrm{C}\right)$ for $4 \mathrm{~h}$ followed by filtration. The residues were repeated again under the same conditions, then evaporated in a rotary evaporator (Buchi-water bath-B-480,

Switzerland) less than $40{ }^{\circ} \mathrm{C}$. The extracts green tea and green coffee beans extracts (GTE or GCE) were collected and stored at $20{ }^{\circ} \mathrm{C}$ until used.

\section{Identification of phenolic compounds in green tea and coffee powder using HPLC}

Phenolic components were identification and quantification by HPLC as described by Schieber et. al., (2001) and modified by El-Houfi (2015). This assay was conducted in Food Chem. Lab., Food Technol. Res. Institute, ARC, Egypt.

\section{Yoghurt manufacture}

Fresh low-fat buffalo's milk ( $1.5 \%$ fat) was fortified with $2 \%$ skim milk powder, heated at $90{ }^{\circ} \mathrm{C}$ for 10 min, and cooled to $43^{\circ} \mathrm{C}$. The treated milk was divided into 3 portions. The first portion was left without any additives and serve as a control (C). Second portion was supplemented with GTE at level 1\%, (T1). The third portion was supplemented with green GCE at level 1\%, (T2) before inoculation. Starter was added to all treatments at the rate of $3 \%$ and incubated at $43^{\circ} \mathrm{C}$ for $4 \mathrm{~h}$ until complete coagulation followed by cooling overnight in the refrigerator at $7^{0} \mathrm{C}$.

\section{Methods of analysis}

\section{Chemical composition of yoghurt}

Resultant yoghurt, from all treatments, was chemically examined for total solids, fat, $\mathrm{pH}$ and acid value as described by AOAC (2007). Total protein was resolute by Kjeldhel technique like described in the AOAC (2007).

\section{Rheological properties}

\section{Viscosity}

Viscosity of yoghurt samples were determined by the method of Askar and Tretow (1993) utilization of Rotational Viscometer Type Lab. Line Model 5437. readers were evaluated by cps.

\section{Syneresis}


Syneresis was determined according to Aryana (2003). The syneresis index (\%) was calculated as $\mathrm{mL}$ of whey per $100 \mathrm{~mL}$ of each first test.

\section{Sensory evaluation}

Yoghurt samples were organoleptically examined after refrigeration according to Hamdy et al., (1972).

\section{Biological experimental plan:}

Thirty well adult male albino rats weighting between 110 and $120 \mathrm{~g}$ were in the animal house of Faculty of Agriculture, Zagazig, University, in stainless steel cages with monitor base in a controlled setting with $12 \mathrm{~h}$. light and $12 \mathrm{~h}$. dark cycles. All rats groups have giving on the basal diet which prepared according to AIN (1993) for one week as adaptation period. After adaptation, six rats were kept on basal diet and tap water along the period of experimental as negative control group (G1). Others rats groups were fed on high fat diet according to Negm (2002) to induce obesity for 2 weeks and separated to four groups randomly as follows (six rats of all groups). Group1 (G1),negative control rats were fed on basal diet; Group 2 (G2): positive control rats fed on high fat diet; Group 3 (G3), rats fed on high fat and 10\% yoghurt (without additives); Group 4 (G4),rats fed on high fat diet and 10\% yoghurt adding to green tea extract; and Group 5 (G5), rats fed on high fat diet and 10\% yoghurt adding to green coffee extract.

\section{Body weight and organ weights of rats}

At the end of the experiment through, period 8 weeks, the quantities of diet consumed and wasted were recorded every day to calculate the food intake and body weight was collected of all week. Food efficiency ratio (F.E.R) was designed by Proll et al., (1998) according to using the following equation. F.E.R $=$ Body weight gain (60 days) / Food consumed (60 days). After all rats were killed, liver, kidney and heart origin were weighted.

\section{Biochemical analysis of serum samples}

Blood samples were collected using $5 \mathrm{ml}$ syringe by cardiac puncture after fasting the rats during the night and centrifuged at $3000 \mathrm{rpm}$ for $10 \mathrm{~min}$ to split serum. Total cholesterol, HDL-C and triglyceride levels were expected in serum according to Devi and Sharma, (2004). LDL -C was planned following the method of Johnson et al., (1997). Liver enzymes, Alanine Amino Transferase (ALT), Aspartate Amino Transferase (AST) and total serum protein were evaluated using Kits (Young, 2001). Kidney function was calculated as serum creatinine and blood urea nitrogen by enzymatic colorimetric methods using commercial kits Sigma-Aldrich (Young 2001).

\section{Histopathological tissues}

Specimens from liver, kidney and heart were collected after scarified rats, from different treatments, and fixed in $10 \%$ impartial formalin and embedded in paraffin. Tissues of five microns thickness were 
regimented, discoloured by haematoxylin and eosin then microscopically examined by declare by

Suvarna, et.al., (2013).

Statistical examinations

Statistical analysis of the obtained data was accepted of according to the method explained by Steel and Torrie, (1980).

\section{Results And Discussion}

Total phenolic (TPC) and total flavonoids compounds (TFC) of green tea and coffee powder

Results in Table (1) recorded that green tea powder had total phenolic (TPC) $86.60 \mathrm{mg} / 100 \mathrm{~g}$ and total flavonoids $54.26 \mathrm{mg} / 100 \mathrm{~g}$ while green coffee powder had $44.29 \mathrm{mg} / 100 \mathrm{~g}$. TPC and total flavonoids $6.68 \mathrm{mg} / 100 \mathrm{~g}$. These results are in accordance with that

Table (1). Total phenolic compounds (TPC) and total flavonoids compounds (TFC) of green tea (GTE) or coffee (GCE)

\begin{tabular}{|lll|}
\hline Compounds $(\mathrm{mg} / 100 \mathrm{~g})$ & GTE & GCE \\
\hline Total phenolic TPC & $86.60 \pm 8.37$ & $44.29 \pm 5.44$ \\
\hline Total flavonoids TFC & $54.26 \pm 4.56$ & $6.68 \pm 1.67$ \\
\hline
\end{tabular}

obtained by Enaam et.al., (2017) who reported that the polyphenols found in tea are

normally flavonoids. Also, Scalbert et. al., (2005) showed that green tea had a high

in polyphenols content of numerous of biological activities like a anticarcinogenic, antiviral, antiallergic, anti- inflammatory and immune-stimulating things that considering of functional properties. Furthermore, Marhamatizadeh et. al., (2014) reported that numerous compounds with pharmacological effects were found in green coffee and amounts of soluble fiber and phenolic compounds.

\section{Identification of phenolic compounds by HPLC}

Table (2) demonstrate the total phenolic compounds found in green tea or coffee extracts. The results presented the major phenolic compounds in green tea w. They were Coumarin acid $(423.82 \mathrm{mg} / 100 \mathrm{~g})$ then, Ferulic acid $(312.84 \mathrm{mg} / 100 \mathrm{~g})$ while the green coffee was Quercetin $(100.93 \mathrm{mg} / 100 \mathrm{~g})$, Kaemoferol $(15.38 \mathrm{mg} / 100 \mathrm{~g})$ then Ferulic acid $(96.75 \mathrm{mg} / 100 \mathrm{~g})$ and additional compounds find in much lesser quantities. These results are in agree with Enaam et.al., (2017) who appeared that the experimental variations between different studies may be recognized to variations in the process, green tea and coffee leaves powder variety. Also, Shabboo and Ahmad (2015) indicated that only Twenty-one to Twenty-seven compounds were detected of phenolic and flavanoids in green tea extract. Furthermore, Beckman and 
Ames (1998) recognized at polyphenolic compounds had biological activities by free radical scavengers because of redox property that play vital roles in a lot of hazard diseases for example cancer, atherosclerosis and diabetes.

Table (2). Identification of phenolic compounds in green tea or coffee powder ( $\mathrm{mg} / 100 \mathrm{~g})$ as determined by HPLC

\begin{tabular}{|lll|}
\hline Compounds & Green Tea & Green Coffee \\
\hline Coumarin acid & $423.82 \pm 19.67$ & $21.77 \pm 2.56$ \\
\hline Ferulic acid & $312.84 \pm 16.90$ & $96.75 \pm 10.34$ \\
\hline Resorcinol & $0.798 \pm 0.14$ & $15.88 \pm 3.56$ \\
\hline Quercetin & $94.27 \pm 10.45$ & $100.93 \pm 7.99$ \\
\hline Kaempferol & $27.49 \pm 2.11$ & $15.38 \pm 2.67$ \\
\hline Naphthaline & ND & $1.32 \pm 0.34$ \\
\hline Phenantherine & ND & ND \\
\hline
\end{tabular}

\section{Chemical composition of yoghurt adding to green tea or coffee extracts}

The chemical composition of yoghurt adding to $1 \%$ green tea or $1 \%$ coffee extract were represented in Table (3). The results indicated that yoghurt adding to green coffee extract (T2) had significantly $(p \leq 0.05)$ high protein $(4.29 \mathrm{~g} / 100 \mathrm{~g})$ and fat

$(1.51 \mathrm{~g} / 100 \mathrm{~g})$ while the less total solids compare with the yoghurt control. The protein (3.96 -4.29 $\mathrm{g} / 100 \mathrm{~g}$ ) of yoghurt adding to green tea or coffee extracts slightly increased respectively and total solids by increasing the percentage added. On the other hand, adding natural, green tea or coffee extracts, to milk had not influence of the fat rate of the resulting yoghurt as study by Yousef et al., (2013).

\section{Table (3): Chemical composition $(\mathrm{g} / 100 \mathrm{~g})$ of yoghurt adding to green tea or coffee extract}

\begin{tabular}{|llll|}
\hline Total protein & Total fat & Total solids & Treatments \\
\hline $3.81 \pm 0.0608^{\mathrm{c}}$ & $1.57 \pm 0.0577^{\mathrm{a}}$ & $11.23 \pm 0.129^{\mathrm{a}}$ & $\mathrm{C}$ (control yoghurt) \\
\hline $3.95 \pm 0.076^{\mathrm{b}}$ & $1.42 \pm 0.0577^{\mathrm{a}}$ & $11.49 \pm 0.115^{\mathrm{b}}$ & T1(yoghurt+ $1 \%$ green tea extract) \\
\hline $4.29 \pm 0.124^{\mathrm{a}}$ & $1.51 \pm 0.0577^{\mathrm{b}}$ & $11.49 \pm 0.115^{\mathrm{b}}$ & T2(yoghurt+ 1\%green coffee extract) \\
\hline 0.1399 & 1.511 & 0.0325 & LSD \\
\hline
\end{tabular}

Values with different letters in the same column are significantly different $(P \leq 0.05)$. 


\section{Rheological properties}

Changes in yoghurt adding to green tea or coffee extract on rheological properties are shown in Table (4). The results indicated that high viscosity was found in yoghurt coffee extract (T2, $2500 \mathrm{cps}$ ) then yoghurt tea extract $(T 1,2400 \mathrm{cps})$ inverse to whey syneresis, the highest value was control yoghurt (C). Adding green tea or coffee extracts to yoghurt may be increase viscosity a key defensive effect on the gel-factors. Although, the $\mathrm{pH}$ and titratable acidity of yoghurt adding to tea or coffee extracts was increased but low significantly. These differences among results may be reproduce the effect of green tea or coffee extract adding to yogurt. These results are in agree with Marhamatizadeh et. al., (2014) who found that addition of coffee extract might cause an increase viscosity of coffee flavored milk and yoghurt. Also, Mohammad et.al., (2013) establish that addition green tea extract had significant effect of the acidity yoghurts and reduce $\mathrm{pH}$ values for milk or yoghurt supplemented. Furthermore, Amirdivani and Baba (2013) indicated that the green tea yoghurts have a lesser syneresis rates compare to control yoghurt.

Table (4): Rheological properties (viscosity and synersis), acidity and $\mathrm{pH}$ in yoghurt supplemented green tea or coffee extracts

\begin{tabular}{|lllll|}
\hline Treatments & $\begin{array}{l}\text { Viscosity } \\
\text { (CPS) }\end{array}$ & $\begin{array}{l}\text { Synersis } \\
(100 \mathrm{ml})\end{array}$ & $\begin{array}{l}\text { Acid value } \\
(\mathrm{mg} \\
\mathrm{KOH} / \mathrm{g} \text { oil })\end{array}$ & $\mathrm{pH}$ \\
\hline C (control yoghurt) & $2199 \pm 1057^{\mathrm{c}}$ & $\begin{array}{l}20.55^{\mathrm{a}} \\
0.44^{\mathrm{a}}\end{array}$ & $0.82 \pm 0.08^{\mathrm{a}}$ & $4.43 \pm 0.05^{\mathrm{b}}$ \\
\hline T1(yoghurt+ 1\% green tea extract) & $2400 \pm 57^{\mathrm{b}}$ & $35.46 \pm 0.55^{\mathrm{c}}$ & $0.90 \pm 0.05^{\mathrm{a}}$ & $4.58 \pm 0.06^{\mathrm{a}}$ \\
\hline $\begin{array}{l}\text { T2(yoghurt+ 1\%green coffee } \\
\text { extract) }\end{array}$ & $2500 \pm 57^{\mathrm{a}}$ & $\begin{array}{l}30.62^{\mathrm{b}} \\
0.61^{\mathrm{b}}\end{array}$ & $1.04 \pm 0.03^{\mathrm{a}}$ & $4.53 \pm 0.05^{5 \mathrm{~b}}$ \\
\hline LSD & 0.755 & 2.489 & 0.2880 & 1.511 \\
\hline
\end{tabular}

Values with different letters in the same column are significantly different $(P \leq 0.05)$. C:

\section{Sensory evaluation of yoghurt adding to green tea or coffee extract}

The sensory evaluation of yoghurt is exposed in Table (5). The data appeared that there were no significant differences higher sensory scores reported flavor in

Table (5): Sensory evaluation of law fat yoghurt adding to green tea or coffee extracts 


\begin{tabular}{|lllll|}
\hline Treatments & $\begin{array}{l}\text { Appearance } \\
(10)\end{array}$ & $\begin{array}{l}\text { Flavor } \\
(50)\end{array}$ & $\begin{array}{l}\text { Body and texture } \\
(40)\end{array}$ & $\begin{array}{l}\text { Total } \\
(100)\end{array}$ \\
\hline C (control yoghurt) & $8.22 \pm 0.83^{\mathrm{a}}$ & $47.22 \pm 3.19^{\mathrm{a}}$ & $38.11 \pm 1.69^{\mathrm{a}}$ & $93.88 \pm 3.95^{\mathrm{a}}$ \\
\hline $\begin{array}{l}\text { T1(yoghurt+ 1\% green tea } \\
\text { extract) }\end{array}$ & $9.33 \pm 0.50^{\mathrm{a}}$ & $48.11 \pm 1.90^{\mathrm{b}}$ & $39.0 \pm 1.58^{\mathrm{a}}$ & $96.44 \pm 3.34^{\mathrm{a}}$ \\
\hline $\begin{array}{l}\text { T2(yoghurt+ 1\%green coffee } \\
\text { extract) }\end{array}$ & $8.22 \pm 0.83^{\mathrm{b}}$ & $\begin{array}{l}46.55 \pm 1.58 \\
\mathrm{a}\end{array}$ & $38.778 \pm 1.48^{\mathrm{a}}$ & $93.44 \pm 2.60^{\mathrm{a}}$ \\
\hline SD & 0.7191 & 2.2702 & 1.5440 & 3.2834 \\
\hline
\end{tabular}

Values with different letters in the same column are significantly different $(P \leq 0.05)$.

green tea and coffee yoghurt extract more than control. Sensory analysis found that yoghurt green tea and coffee extract were improved than the control yoghurt. These results agree Amirdivani and Baba (2013) determined that the lowest score smell of moringa yoghurts and appearance and received excellent while, the highest score were yoghurts placed in group one and green tea and moringa yoghurts came in the second group, although both fortified yoghurts inserted a good score level. While, Marhamatizadeh et. al., (2014) demonstrated that there were significant between the yoghurt samples adding to coffee extract and provide to favorable taste and color. These results agreement with Mohammad et.al., (2013).

\section{Body weight of obese rats feeding on yoghurt adding to green tea or coffee beans extract}

As shown in Table (6) feeding obese rats on yoghurt adding to green tea and coffee extract indicated that positive control group had the highest significant increase body weight, food intake and feed efficiency value compared with negative control group. Which the mean value of body weight gain, food in general, fed obese rats on yoghurt adding to green tea or coffee extracts led to significant decrease in BWG, $\mathrm{FI}$ and FER compared to rats groups fed on high fat diet. Green tea or coffee extracts are high in bioactive active compounds such as phenolic and flavonoids, might be help in fiery fats and weight loss. These results agree with El-Shaer et al. (2016). Green tea demonstrated to defend skin from UV harm and control body weight (Dulloo et. al., 1999 and Enaam et. al., 2017). These results agree Nagham and Alhamhany (2018) and Williams (2008), Who appeared that consumption of coffee had significantly lower body mass index and greater level of physical activity.

Other studies included that green tea had potential therapeutic by weight loss and concluded that antioxidant activity and catechins inhibiting catechol-0-methyltransferase that lipolytic route and green tea had effect of green tea on human health (Sarah, and Manami, 2020).

Table (6): Body weight of obese rats feeding on yoghurt supplemented green tea and coffee extracts 


\begin{tabular}{|llll|}
\hline Groups & $\begin{array}{l}\text { Body weight gain }(\mathrm{g} / 60 \\
\text { day) }\end{array}$ & $\begin{array}{l}\text { Food intake } \\
(\mathrm{g} / \text { day })\end{array}$ & FER \\
\hline G1 (Negative) & $61.01 \pm 3.170^{\mathrm{b}}$ & $\begin{array}{l}20.945 \pm \\
0.405^{\mathrm{ab}}\end{array}$ & $\begin{array}{l}0.0246 \pm \\
0.0214^{\mathrm{b}}\end{array}$ \\
\hline G2 (Positive, Obese) & $148.88 \pm 12.500^{\mathrm{a}}$ & $26.795 \pm 0.815^{\mathrm{a}}$ & $0.0924 \pm 5.00^{\mathrm{a}}$ \\
\hline G3 (Obese +10\% yoghurt) & $38.92 \pm 2.2345^{\mathrm{c}}$ & $9.135 \pm 8.13^{\mathrm{b}}$ & $0.0357 \pm 5.00^{\mathrm{b}}$ \\
\hline $\begin{array}{l}\text { G4 (Obese }+10 \% \text { yoghurt } \\
+ \text { GTE) }\end{array}$ & $24.35 \pm 1.45^{\mathrm{cd}}$ & $15.545 \pm 1.105^{\mathrm{ab}}$ & $0.0263 \pm 3.400^{\mathrm{b}}$ \\
\hline $\begin{array}{l}\text { G5 (Obese }+10 \% \text { yoghurt } \\
+\mathrm{GCE})\end{array}$ & $17.44 \pm 0.870^{\mathrm{d}}$ & $15.230 \pm 1.110^{\mathrm{ab}}$ & $0.0191 \pm 4.500^{\mathrm{b}}$ \\
\hline LSD & 20.949 & 15.833 & 0.0401 \\
\hline
\end{tabular}

Values with different letters in the same column are significantly different $(P \leq 0.05)$

\section{Effect of feeding yoghurt adding to green tea or coffee extracts on the heart, liver and kidney organ weights of rats}

Results in Table (7) illustrated the effect of feeding yoghurt adding to green tea and coffee extract on heart, kidney and liver of obese rats. Also, there were not significant by heart weights tissues while kidney and liver weights were significant differences. Although, kidney and liver weights of group feeding on yoghurt supplemented green tea extract (G4) had the lowest values (1.55/g and $5.88 / \mathrm{g}$ respectively) following (G5) group feeding on yoghurt supplemented green coffee extract (1.55/g and $5.88 / \mathrm{g}$ respectively). Although, the highest values of heart, kidney and liver weights was group of obese rats fed on feeding normal (G2) comparative with the others groups. In similar study, Mohamed et. al., (2017) observed that yoghurt with plant extracts had the therapeutic effects and decreasing the liver weight. The present study showed that the increase in liver weight was connected with liver lipid increase.

Table (7): Effect of feeding yoghurt adding to green tea or coffee extract on the heart, liver and kidney organs weights of rats at the end of feeding period. 


\begin{tabular}{|llll|}
\hline Rats Groups & $\begin{array}{l}\text { Heart } \\
\text { (weight/ g) }\end{array}$ & $\begin{array}{l}\text { Kidney } \\
\text { (weight/ g) }\end{array}$ & $\begin{array}{l}\text { Liver } \\
\text { (weight/ g) }\end{array}$ \\
\hline G1 (Negative) & $0.544 \pm 0.272^{\mathrm{a}}$ & $1.988 \pm 0.081^{\mathrm{ab}}$ & $9.776 \pm 0.352^{\mathrm{b}}$ \\
\hline G2 (Positive, Obese) & $0.724 \pm 0.312^{\mathrm{a}}$ & $2.320 \pm 0.197^{\mathrm{a}}$ & $11.068 \pm 0.232^{\mathrm{a}}$ \\
\hline G3 (Obese +10\% yoghurt) & $0.744 \pm 0.023^{\mathrm{a}}$ & $1.790 \pm 0.121^{\mathrm{ab}}$ & $6.323 \pm 0.284^{\mathrm{c}}$ \\
\hline G4 (Obese +10\% yoghurt +GTE) & $0.6363 \pm 0.60^{\mathrm{a}}$ & $1.553 \pm 0.285^{\mathrm{b}}$ & $5.880 \pm 0.477^{\mathrm{c}}$ \\
\hline G5 (Obese $+10 \%$ yoghurt +GCE) & $0.711 \pm 0.0211^{\mathrm{a}}$ & $1.778 \pm 0.125^{\mathrm{ab}}$ & $6.030 \pm 0.080^{\mathrm{c}}$ \\
\hline L.S. D & 0.636 & 0.644 & 1.1227 \\
\hline
\end{tabular}

Values with different letters in the same column are significantly different $(P \leq 0.05)$

Effect of feeding yoghurt adding to green tea or coffee extracts on serum lipids profile of obese rats

Positive control group proved a significant difference high in the serum values of TG, TC and LDL-C Table 8. On the other hand, HDL-C was decreased when compared with the values of negative control of rats. The lowest decrease in the values of serum total cholesterol and (LDL-C , V LDL-C) and an increase in values of HDL-C were observed in groups (G4 and G5) fed on yoghurt adding to green tea and coffee extract compared to positive control group (G2) although increasing TG in positive control group where TG harm on liver because of fatty liver diseases. These results agree with that observed by Mohamed et.al., (2017), and Nagham and Alhamhany (2018), who showed that green coffee is useful by reduce of the BMI following the experimental trials which due to decrease of VLDL and high in the

HDL females for obesity. These results agree with Xu et al.2015 and Chang et a/2015. Green coffee and green tea extract goods better the metabolic profile and improved hypoglycemic and hypolipidemic (Mifetika et al., 2020).

Table (8): Effect of feeding yoghurt adding to green tea or coffee extracts on serum lipid profile of obese rats. 


\begin{tabular}{|c|c|c|c|c|c|c|}
\hline $\begin{array}{l}\text { Feeding } \\
\text { period }\end{array}$ & Rats Groups & $\begin{array}{l}\text { Triglycerides } \\
(\mathrm{mg} / \mathrm{dl})\end{array}$ & $\begin{array}{l}\text { Total } \\
\text { cholesterol } \\
(\mathrm{mg} / \mathrm{dl})\end{array}$ & $\begin{array}{l}\text { HDL-c } \\
(\mathrm{mg} / \mathrm{dl})\end{array}$ & $\begin{array}{l}\text { LDL-C } \\
(\mathrm{mg} / \mathrm{dl})\end{array}$ & $\begin{array}{l}\text { VLDL } \\
\mathrm{c}(\mathrm{mg} / \mathrm{dl})\end{array}$ \\
\hline \multirow[t]{2}{*}{$\begin{array}{l}\text { At the } \\
\text { beginning }\end{array}$} & $-\mathrm{Ve}$ & $\begin{array}{l}140.31 \pm \\
0.27^{c}\end{array}$ & $\begin{array}{l}112.18 \pm \\
3.27^{b}\end{array}$ & $\begin{array}{l}55.53 \pm \\
0.22^{\mathrm{c}}\end{array}$ & $\begin{array}{l}31.61 \pm \\
0.80^{\mathrm{c}}\end{array}$ & $\begin{array}{l}28.31 \pm \\
0.31 \mathrm{~cd}\end{array}$ \\
\hline & $+\mathrm{Ve}$ & $\begin{array}{l}151.80 \pm \\
0.49^{b}\end{array}$ & $\begin{array}{l}121.65 \pm \\
0.87^{a}\end{array}$ & $\begin{array}{l}44.627 \pm \\
0.57^{\mathrm{e}}\end{array}$ & $\begin{array}{l}45.99 \pm \\
1.58^{\mathrm{a}}\end{array}$ & $\begin{array}{l}30.36 \\
\pm 0.09^{b}\end{array}$ \\
\hline \multirow[t]{5}{*}{$\begin{array}{l}\text { At the } \\
\text { end }\end{array}$} & G1 (Negative) & $\begin{array}{l}134.92 \pm \\
2.88^{\mathrm{C}}\end{array}$ & $\begin{array}{l}115.99 \pm \\
1.15^{\mathrm{b}}\end{array}$ & $\begin{array}{l}63.95 \pm \\
0.94^{a}\end{array}$ & $\begin{array}{l}25.06 \pm \\
1.48^{d}\end{array}$ & $\begin{array}{l}26.98 \pm \\
0.57^{d}\end{array}$ \\
\hline & $\begin{array}{l}\text { G2 (Positive, } \\
\text { Obese) }\end{array}$ & $\begin{array}{l}164.72 \pm \\
1.75^{\mathrm{a}}\end{array}$ & $\begin{array}{l}124.23 \pm \\
0.32^{\mathrm{a}}\end{array}$ & $\begin{array}{l}49.00 \pm \\
0.76^{d}\end{array}$ & $\begin{array}{l}42.29 \pm \\
0.69^{\mathrm{b}}\end{array}$ & $\begin{array}{l}32.94 \pm \\
0.35^{\mathrm{a}}\end{array}$ \\
\hline & $\begin{array}{l}\text { G3 (Obese } \\
+10 \% \text { yoghurt) }\end{array}$ & $\begin{array}{l}152.72 \pm \\
1.78^{\mathrm{b}}\end{array}$ & $\begin{array}{l}103.90 \pm \\
0.78^{c}\end{array}$ & $\begin{array}{l}58.43 \pm \\
2.15^{b c}\end{array}$ & $14.93 \pm 1.60 \mathrm{e}$ & $\begin{array}{l}30.54 \pm \\
0.36^{\mathrm{b}}\end{array}$ \\
\hline & $\begin{array}{l}\text { G4 (Obese } \\
+10 \% \text { yoghurt } \\
+ \text { GTE) }\end{array}$ & $\begin{array}{l}138.78 \pm \\
4.92^{c}\end{array}$ & $\begin{array}{l}115.03 \pm \\
1.83^{b}\end{array}$ & $\begin{array}{l}62.45 \pm \\
1.64^{\mathrm{a}}\end{array}$ & $\begin{array}{l}24.81 \pm \\
0.84 d^{d}\end{array}$ & $\begin{array}{l}27.75 \pm \\
0.98^{d}\end{array}$ \\
\hline & $\begin{array}{l}\text { G5 (Obese } \\
+10 \% \text { yoghurt } \\
+ \text { GCE) }\end{array}$ & $\begin{array}{l}149.32 \pm \\
2.52^{\mathrm{b}}\end{array}$ & $\begin{array}{l}101.35 \pm \\
0.73^{c}\end{array}$ & $\begin{array}{l}60.37 \pm \\
1.44^{\mathrm{ab}}\end{array}$ & $11.59 \pm 1.82^{f}$ & $\begin{array}{l}29.86 \pm \\
0.50^{\mathrm{bc}}\end{array}$ \\
\hline
\end{tabular}

Values with different letters in the same column are significantly different $(P \leq 0.05)$

HDL females for obesity. In similar study, Sharadi and Eldad (2000) stimulated fatty liver disease is connected with hyperlipidemia and obesity also found that LDL-C is a main risk factor for heart diseases whereas HDL-C is a cardio defensive. This decrease may be due to the diet contained yoghurt supplemented green tea or coffee extracts for total phonolic and total flavonoids which include the antioxidative effects. Also, Isolauriet.al., (2002), showed that eating yogurt can be improve immune accent decreasing rate of diseases such as cancer and gastrointestinal confusions. Furthermore, Shabboo and Ahmad (2015) indicated that adding to green tea with milk presented the higher antioxidant activity. Finally, Marhamatizadeh et.al., (2014) indicated that coffee extract with milk or yoghurt had functional properties with potential therapeutic.

\section{Effects of feeding yoghurt adding to green tea or coffee extracts on liver and kidney functions of obese rats}

From results Table (9) it could be observed that all yoghurt groups administrated with different extracts had significant increase in total protein parameters when compared with the negative control group Also, it could be observed that yoghurt supplemented green tea and coffee extract groups had significant decrease in serum liver function assessments (ALT and AST) and serum kidney function assessments (urea and creatinine) comparing with positive control. The best treatment was yoghurt adding to green coffee extract (G5) which had lowest value of liver and kidney function parameters followed by yoghurt 
adding to green tea extract (G4). Also, these treatments induced suppression of the increased ALT and AST activities $(P \leq 0.05)$. These results agree with Enaamet.al., (2017) who indicated that polyphenols

Table (9): Effect of feeding yoghurt adding to green tea or coffee extract on liver and kidney functions of obese rats

\begin{tabular}{|c|c|c|c|c|c|c|}
\hline $\begin{array}{l}\text { Feeding } \\
\text { period }\end{array}$ & Rats Groups & $\begin{array}{l}\text { Total } \\
\text { protein } \\
(\mathrm{g} / \mathrm{dl})\end{array}$ & $\begin{array}{l}\text { ALT } \\
(\mathrm{U} / \mathrm{L})\end{array}$ & $\begin{array}{l}\text { AST } \\
(\mathrm{U} / \mathrm{L})\end{array}$ & $\begin{array}{l}\text { Creatinine } \\
(\mathrm{mg} / \mathrm{dl})\end{array}$ & $\begin{array}{l}\text { Urea } \\
(\mathrm{mg} / \mathrm{dl})\end{array}$ \\
\hline \multirow[t]{2}{*}{$\begin{array}{l}\text { At the } \\
\text { beginning }\end{array}$} & $-\mathrm{Ve}$ & $\begin{array}{l}7.29 \pm \\
0.15^{\mathrm{bc}}\end{array}$ & $\begin{array}{l}46.33 \pm \\
1.66^{\mathrm{b}}\end{array}$ & $\begin{array}{l}19 \pm \\
0.02^{b}\end{array}$ & $1.21 \pm 3.32^{b}$ & $\begin{array}{l}25.50 \pm \\
1.70^{d}\end{array}$ \\
\hline & $+\mathrm{Ve}$ & $\begin{array}{l}6.70 \pm \\
0.12^{\mathrm{ab}}\end{array}$ & $\begin{array}{l}77.33 \pm \\
3.17^{\mathrm{a}}\end{array}$ & $\begin{array}{l}23.0 \pm \\
0.89^{b}\end{array}$ & $1.33 \pm 0.02^{\mathrm{a}}$ & $\begin{array}{l}38.84 \pm \\
0.63^{\mathrm{a}}\end{array}$ \\
\hline \multirow[t]{5}{*}{ At the end } & G1 (Negative) & $\begin{array}{l}7.040 \pm \\
0.040^{\mathrm{a}}\end{array}$ & $\begin{array}{l}49.33 \pm \\
1.3333^{b}\end{array}$ & $\begin{array}{l}21.667 \pm \\
1.33^{b}\end{array}$ & $\begin{array}{l}0.99 \pm 5.77 \\
c\end{array}$ & $\begin{array}{l}30.19 \pm \\
0.16^{c}\end{array}$ \\
\hline & G2 (Positive, Obese) & $\begin{array}{l}6.47 \pm \\
0.07^{\mathrm{e}}\end{array}$ & $\begin{array}{l}80.66 \pm \\
3.17^{a}\end{array}$ & $\begin{array}{l}39.0 \pm \\
8.00^{\mathrm{a}}\end{array}$ & $1.17 \pm 0.03^{b}$ & $\begin{array}{l}38.40 \pm \\
0.84^{\mathrm{a}}\end{array}$ \\
\hline & $\begin{array}{l}\text { G3 (Obese }+10 \% \\
\text { yoghurt) }\end{array}$ & $\begin{array}{l}6.90 \pm \\
0.04^{d}\end{array}$ & $\begin{array}{l}46.33 \pm \\
1.66^{\mathrm{b}}\end{array}$ & $\begin{array}{l}13.0 \pm \\
0.00^{b}\end{array}$ & $0.93 \pm 6.43^{d}$ & $\begin{array}{l}32.77 \pm \\
0.83^{c}\end{array}$ \\
\hline & $\begin{array}{l}\text { G4 (Obese }+10 \% \\
\text { yoghurt +GTE) }\end{array}$ & $\begin{array}{l}7.296 \pm \\
0.018^{\mathrm{cd}}\end{array}$ & $48 \pm 0.00^{b}$ & $\begin{array}{l}17.0 \pm \\
2.00^{\mathrm{b}}\end{array}$ & $\begin{array}{l}1.02 \pm \\
0.012^{c}\end{array}$ & $\begin{array}{l}37.85 \pm \\
0.011^{\mathrm{ab}}\end{array}$ \\
\hline & $\begin{array}{l}\text { G5 (Obese }+10 \% \\
\text { yoghurt }+\mathrm{GCE})\end{array}$ & $\begin{array}{l}7.40 \pm \\
0.08 \mathrm{~cd}\end{array}$ & $\begin{array}{l}44.66 \pm \\
1.66^{\mathrm{b}}\end{array}$ & $\begin{array}{l}17.0 \pm \\
2.00^{b}\end{array}$ & $\begin{array}{l}1.02 \pm \\
1.070^{\mathrm{c}}\end{array}$ & $\begin{array}{l}35.60 \pm \\
0.12^{b}\end{array}$ \\
\hline
\end{tabular}

Values with different letters in the same column are significantly different $(P \leq 0.05)$

containing of tea are majority flavonoids which have anti-oxidative and anti-carcinogenic effects. Also, green tea, had polyphenols with numerous of biological activities such as anticarcinogenic, anti-allergic, anti- inflammatory and immune-stimulating effects (Scalbert et al. 2005). Furthermore, Shabboo and Ahmad (2015) reported that the containing of green tea with yogurt before fermentation have impart sensory properties connected with tea flavour, antioxidant properties and health benefits by phenolic compounds and highest advantage of yogurt nutrition.

\section{Histopathological examination}

\section{Liver}

Microscopically examination of rats liver in positive control group, appeared in Photo (1). Liver sections showed mild congestion of hepatic veins, portal round cells infiltration beside degenerative and apoptotic changes in a few hepatocytes. While photo (2) sections from liver showed portal and interstitial 
aggregation of macrophages engulfing fat vacuoles, mild portal vascular congestion, round cells aggregations and biliary proliferation. Most of the hepatic cells were normal with normal sinusoids and kupffer cells. However, a few hepatocytes showed cloudy swelling, hydropic degeneration or apoptotic changes. Liver tissue of obese rats fed on yoghurt supplemented green tea extract showed normal hepatic parenchyma, portal area structures, vasculatures and stroma (photo.3). Normal hepatic parenchyma, portal triads structures, vascular tree and stroma. Mild portal round cells infiltration and biliary proliferation were seen in a few cases in photo (4).

\section{Kidney}

Microscopically examination of rats kidney in positive control group in photo (5) revealed congestion of renal blood vessels and capillaries, degenerative changes and necrosis in a moderate number of proximal and distal convoluted tubules, and in the collecting tubules. The most prominent degenerative changes were cloudy swelling, vacuolation and hydropic degeneration. Perivascular edema was seen around a few blood vessels. Intra tubular hyaline casts were detected in some cortical and medullar tubules. Photo (6) observed a few Kidney sections showed cloudy swelling or hydropic degeneration. Most of the renal parenchyma, renal blood vessels and stroma were apparently normal. While photo (7) emerged sections from Kidney revealed normal nephron units with preserved histomorphology, a few renal tubules particularly in the cortex showed cloudy swelling and hydropic degeneration. Kidney tissue in photo (8) appeared normal renal parenchyma with preserved histomorphology of nephron units. a few renal tubules showed cloudy swelling and hydropic degeneration.

\section{Heart}

Microscopically examination of rats heart in positive control group in photo (9) showed inter muscular edema and hyaline degeneration of some cardiomyocytes. Photo (10) concluded that heart section revealed apparently normal blood vessels and cardiomyocytes, however, very mild edema and mild hyaline degenerations in a few muscle fibers were seen. While sections from heart in photo (11) showed normal structures with preserved histomorphology of the cardiomyocytes coronary and inter muscular blood vessels. Photo (12) appeared normal cardiac histomorphology with preserved cardiomyocytes and vasculature in few cases focal inter muscular infiltration of macrophages and eosinophils and hyaline degeneration of some cardiomyocytes were seen.

The beneficial effects of obese rats fed on yoghurt adding to green tea or coffee extracts were confirmed by histopathological examination of the liver, kidney and heart are shown in photo (1-12) respectively. In similar study, Kratz et.al., (2002), reported that green coffee containing of Leptin, and it has been description to order hunger, energy expenditure, thermo genesis, and directive of body weight. Also, ChiChang et.al., (2016) and Change et. al., (2018) showed that obese rats for 4 weeks with green tea extract reduced the accretion of macro vesicular fat in the liver and the structure of adipose sections. They also reported that green tea powder with yoghurt fermentation more supplied these positive cellular effects and anti-inflammatory. Furthermore, Izadi et. al., (2018) showed that coffee and green tea have significantly converse connection with obesity, diabetes, and cardiovascular diseases. 


\section{Conclusion}

Consumption of yoghurt adding to green tea or coffee extracts is effective on decrease obesity and protecting against disease because declining of LDL and raise in the HDL and improving liver and kidney functions. The results demonstrated that antioxidant activity with other components of phenolic components were able to prevent obesity such as lowing liver enzyme activity and kidney functions and severe damage of liver, heart and kidney tissues which were confirmed by histopathological examination in rats. Therefore, it could be recommended that yoghurt supplemented green tea or coffee extracts at concentration of $1 \%$ daily up to 6 weeks has a good functional property, and decreasing obese and its complications.

\section{Declarations}

Author contributions: Shalaby Hanan and Yousif Abd El-Aziz Elhassaneen completed experiments and wrote the main manuscript also prepared the figures and tables and reviewed the manuscript and approved the final manuscript.

Funding: The authors declare that this study did not receive any funding from funding agencies and authors institutions.

Data availability: Data sharing is not applicable to this article as no datasets were generated or examined during the current study

\section{Compliance with ethical standards}

Ethical approval, consent to participate, and consent to publish are not applicable.

Competing interests: The authors declare that they have no competing interests.

\section{References}

AIN. American Institute of Nutrition (1993). Purified diet for laboratory rodent, Final report., J. Nutr., 123, 1939-1951. and O. compactum Benth. J. Essential oil Res., 8(6): 657-664.

Amirdivani, S. and Baba, A. (2013). A rheological properties and sensory characteristics of green tea yogurt during storage. Life Sci. J. 10: 378-390.

AOAC. (2007). Association of Official Analytical Chemists - Official Method of Analysis. (18th Ed.), Benjamin Franklin Station Washington, D.C. 
Askar, A., and Tretow, H. (1993). Quality as source in tropical fruit processing.SprengerVerlag Berlin, Heidelberg, Germany. $57-60$.

Beckman, K.B., and Ames, B.N. (1998). The free radical theory of aging matures. Physiol. Rev. 78:547581.

Cao, C., Wang, L., Lin, X., Mamcarz, M., Zhang, C., and Bai, G. (2011). Caffeine synergizes with another coffee component to increase plasma GCSF. J. Alzheimer's Dis. 2011; 25:323-35.

Chang, C.W., Hsu, Y., J., Chen, Y.M., Huang, W.C., Huang, C.C., and Hsu, M.C., (2015). Effects of combined extract of cocoa, coffee, green tea and garcinia on lipid profiles, glycaemic markers and inflammatory responses in hamsters. BMC Complement Altern. Med. 15:269.

Chang, H., Haram, R., Ting. Z., Chi, H., Han, G. and Sung, G. (2018). Green tea powder supplementation enhances fermentation and antioxidant activity of set-type yogurt. Food Sci. Biotechnol. 27(5):14191427

Chen, H.L., Tung, Y.T., Tsai, C.L., Lai, C.W., Lai, Z.L., Tsai, H.C., Lin, Y.L., Wang, C.H., and Chen, C.M. (2014). Improves fatty liver syndrome by inhibiting the lipogenesis pathway in leptin-deficient ob/ob knockout mice. Int. J. Obese (Lond.);38:1172-9.

Chi-Chang, H., Yu-Tang, T., Wen-Ching, H., Yi-Ming, C., Yi-Ju, H. and Mei-Chich, H., (2016). Beneficial effects of cocoa, coffee, green tea, and garcinia complex supplement on diet induced obesity in rats. BMC Complementary and Alternative Medicine. 16:100

Chiu, .s. (2006).Is green good for you. J. Food Sci. Educ.5.4.70-71.

Devi, R.K., and Sharma, D.K. (2004). Hypolipidemic effect of different extracts of ClerodendroncolebrookianumWalp in normal and high-fat diet fed rats. J. Ethnopharmacol. 90:63-68.

Dórea, J.G., da Costa, T.H., (2005). Is coffee a functional food? Br. J. Nutr. 93:773-82.

Dulloo, A.G., Duret, C., Rohrer, D., Girardier, L., Mensi, N. (1999). Efficacy of a green tea extract rich in catechin polyphenols and caffeine in increasing 24-h energy expenditure and fat oxidation in humans. Am. J. Clin. Nutr. 70: 1040-1045.

El-Shaer, M. K., El-Adawy, A. E., El-Kholie, E. M., and El-Sayed, H. E., (2016). Evaluation of anti-obesity activity of pomegranate leaves and its extracts of induced obese rats. J. Home Econ. 26(2): 131-148.

El-Houfi, F. B. B., (2015). Extraction and identification of phenolic compounds from agro industrial wastes and their antioxidant efficiency on sunflower oil oxidative stability. Ph.D. Thesis, Department of Food Science Technology, Faculty of Agricalture, Damanhur University, Egypt. 
Enaam, S. Shokery, Mohamed, G. E., Asmaa, H. Y., and Reda, I. M., (2017). Effect of green tea and moringa leave extracts fortification on the physicochemical, rheological, sensory and antioxidant properties of settype yoghurt J. Adv. Dairy Res. 5:2.

Hamdy, A.M., El-Kousey, L.A., and Abdel-Latif, R., (1972). A study in the fermented milk (zabady). Agric., Res., Rev., 50(3): 159-168.

Health Canada Food Program (2006). Fact sheet-it's your health: Caffeine. Ottawa, Canada: Health Canada, Internet: Available from: http://www.hcsc. gc.ca/food-aliment/dg/e caffeine.html. [Last accessed on $2006 \mathrm{Jul} 26]$.

Isolauri E., Rautava S., Kalliomäki M., Kirjavainen P., and Salminen, S. (2002). Role of probiotics in food hypersensitivity. Curr. Opin. Allergy Clin. Immunol. 2: 263-271.

Izadi, V., Larijani B., and Azadbakht, L. (2018). Is coffee and green tea consumption related to serum levels of adiponectin and leptin. International J. Preventive Medicine 9: 106-116.

Jae, Hyung, P., Jae-Hoon, B., Sung-Soon, I., and Dae-Kyu, S., (2014). Green tea and type2diabetes. Integr. Med. Res. 3 .4-10.

Johnson, R., McNutt, P., MacMahon, S., and Robson, R., (1997). Use of the friedewald formula to estimate LDL-cholesterol in patients with chronic renal failure on dialysis. Clin. Chem. 43: 2183-2184.

Kratz, M., Eckardstein A., Fobker, M., Buyken, A., and Posny, N. S., (2002). The impact of dietary fat composition on serum leptin concentrations in healthy nonobese men and women. J. Clin. Endocrinol. Metab. 87:5008-14.

Kristel, D., Westerterp, K. R. and Westerterp M. S., (2006). Obesity and thermo genesis related to the consumption of caffeine, ephedrine, capsaicin, and green tea. J. Physiol Regulatory Integrative Comp. Physiol. 292:77-85.

Marhamatizadeh, M. H., Ehsandoost, E., and Gholami P., (2014). The Effect of coffee extract on the growth and viability of Lactobacillus acidophilus and Bifid bacterium bifidum in probiotic milk and yoghurt. Journal of Food Biosciences and Technology. Vol. 4, No. 1, 37-48.

Marhamatizadeh1, M. H., Ehsandoost, E., and Gholami P., (2013). The influence of green tea (Camellia sinensisL.) extract on characteristic of probiotic bacteria in milk and yoghurt during fermentation and refrigerated storage. International Journal of Farming and Allied Sciences. Intl. J. Farm. and Alli. Sci. Vol., 2 (17): 599-606, 2013.

Meydani, M., and Hasan, S.T., (2010). Dietary polyphenols and obesity. Nutrients.;2:737-51.

Mifetika, L., Dwi, A., N., Mohammad, S. R., Nashi, W., Arta, F., and Pramudji, H., (2020). Beneficial effects of green coffee and green tea extract combination on metabolic syndrome improvement by affecting AMPK 
and PPAR-a gene expression. J. Adv. Pharm. Technol. and Res. 11, 2.81.

Mohamed, G. E., Shokery S. E., Youssef, H. A., and Mashaly, R.E., (2017). Protective effects of green tea and moringa leave extracts and their bio-yoghurts against oxidative effects of lead acetate in albino rats. J. Adv. Dairy Res. 5:2.179.

Nagham, N. A., Ekhlas, H. A., (2018). Does green coffee has a positive effect on body mass index and lipid profile in a sample of obese people. J. Pharm. Sci. \& Res. Vol. 10(3), 627-630.

Negm, D. R., (2002). Effect of some common herbs on weight reduction in obese rats.,M.S.c. Thesis, Fac. of Home Econ. Menoufya, Uni.

Proll, J., Petzke, K. J., Ezeagu, I. E., and Metges, C. C., (1998). Low nutrition quality of unconventional tropical crop seeds in rats. J. Nutr., 128: 2014-2022.

Rebello, S.A., Chen, C.H., Naidoo, N., Xu, W., Lee, J., and Chia, K.S., (2011). Coffee and tea consumption in relation to inflammation and basal glucose metabolism in a multiethnic Asian population: A cross sectional study. Nutr. J. 10:61.

Sarah, K. A., and Manami, I., (2020). Green tea and cancer and cardiometabolic diseases: a review of the current epidemiological evidence. European J. Clin. Nutr.

https://doi.org/10.1038/s41430-020-00710-7

Scalbert, A., Manach, C., Morand, C., and Rémésy, C., (2005). Dietary polyphenols and the prevention of diseases. Crit. Rev. Food Sci. Nutr. 45:287-306.

Schieber, A., Stintzing, F.C., and Carle, R., (2001). Byproducts of plant developments. Trends Food Sci., 3(5): $411-420$.

Shabboo, A., and Ahmad, S.., (2015). Green tea yogurt: major phenolic compounds and microbial growth. J. Food Sci. Technol. 52(7):4652-4660.

Sharadi, Y., Eldad, A., (2000). Nonalcoholic fatty liver disease is associated with hyperlipidemia and obesity. Am. J. Med1.09:171.

Steel, R.G.D., and Torrie, J.H., (1980). Principles and Procedures of Statistics. McGraw., New York.

Sumio H., Tomokazu, 0., Noriyuki, M., Yumiko, 0., Yoriyuki, N., and Mamoru, I., (2020). Review Anti-Cancer Effects of Green Tea Epigallocatchin-3-Gallate and Coffee Chlorogenic Acid. Molecules, 25, 4553; doi:10.3390/molecules25194553.

Suvarna, K. S., Christopher, L., and Bancroft, J. D., (2013). Bancroft's theory and practice of histological techniques, 7th Edition. 
Williams, C.J., Fargnoli, J.L., Hwang, J.J., van Dam, R.M., Blackburn, G.L., and Hu, F.B., (2008). Coffee consumption is associated with higher plasma adiponectin concentrations in women with or without type 2 diabetes: A prospective cohort study. Diabetes. Care 2008; 31:504-7.

Xu, Y., Zhang, M., Wu T., Dai, S., Xu, J., and Zhou, Z., (2015). The anti-obesity effect of green tea polysaccharides, polyphenols and caffeine in rats fed with a high-fat diet. Food Funct;;6:297-304.

Yamashita, K., Yatsuya, H., Muramatsu, T., Toyoshima, H., Murohara, T., and Tamakoshi, K., (2012). Association of coffee consumption with serum adiponectin, leptin, inflammation and metabolic markers in Japanese workers: A cross sectional study. Nutr. Diabetes;2: e33.

Young, D.S. (2001). Effects of disease on clinical lab tests, $4^{\text {th }}$ ed. AACC.

Yousef, M., Nateghi, L., and Azadi, E., (2013). Effects of disease on Clinical Lab. Tests, 4th ed. AACC. (www.hayah.cc/from/t34135.html).

\section{Figures}

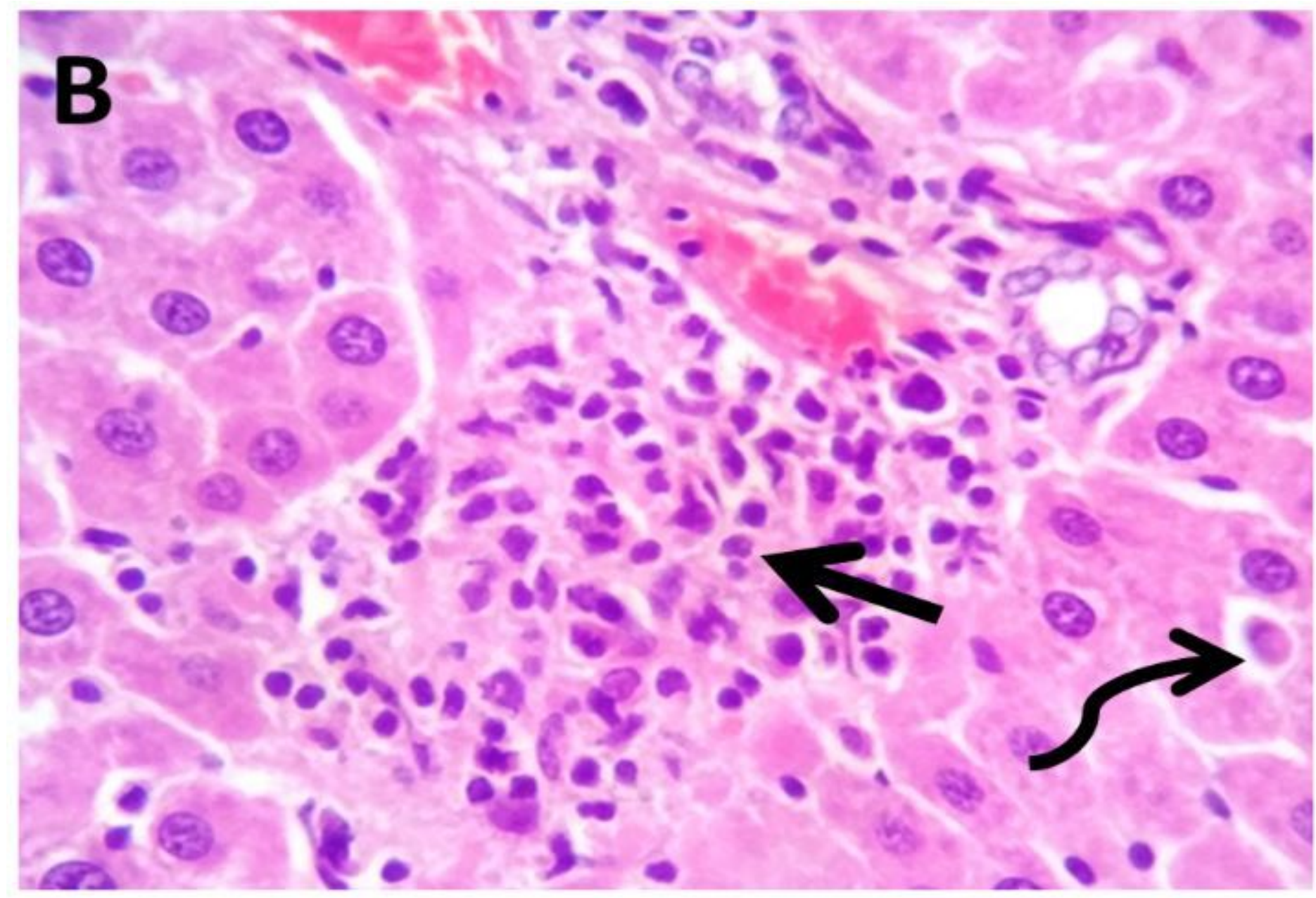

Figure 1 
liver of obese rats fed on feeding normal (positive control group).

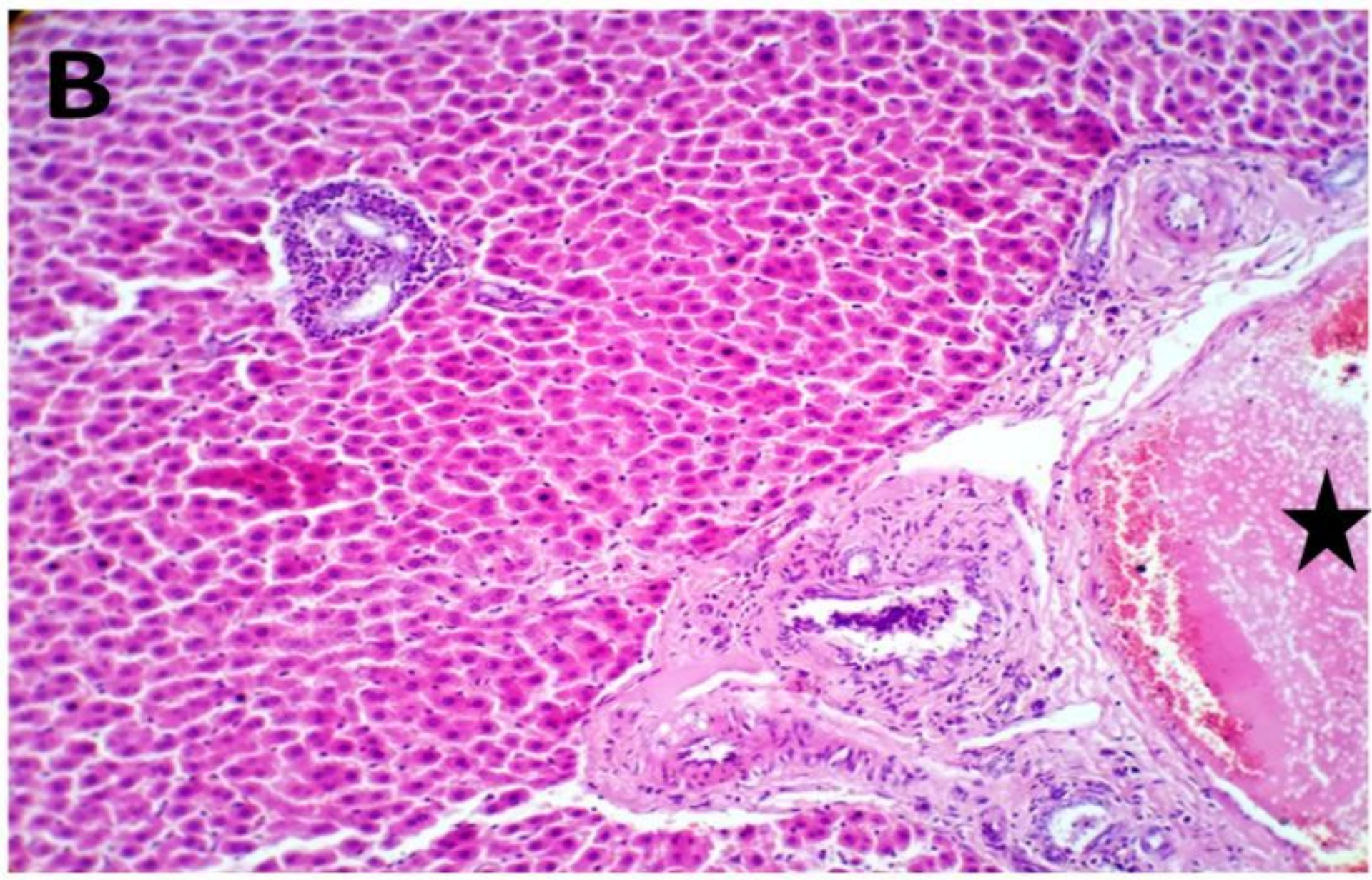

\section{Figure 2}

Liver of obese rats fed on yoghurt without any additives. 


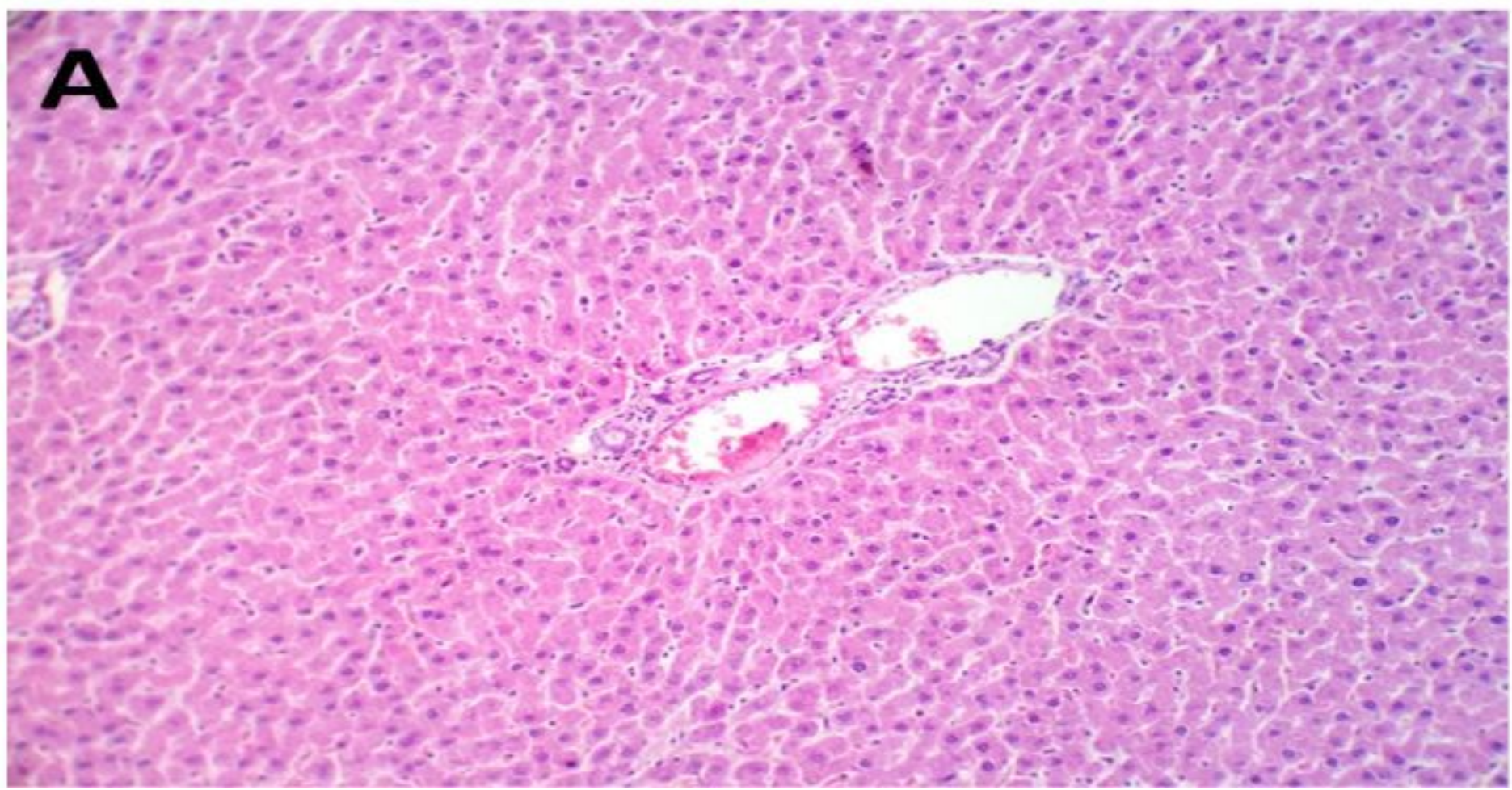

Figure 3

Liver of obese rats fed on yoghurt supplemented green tea extract.

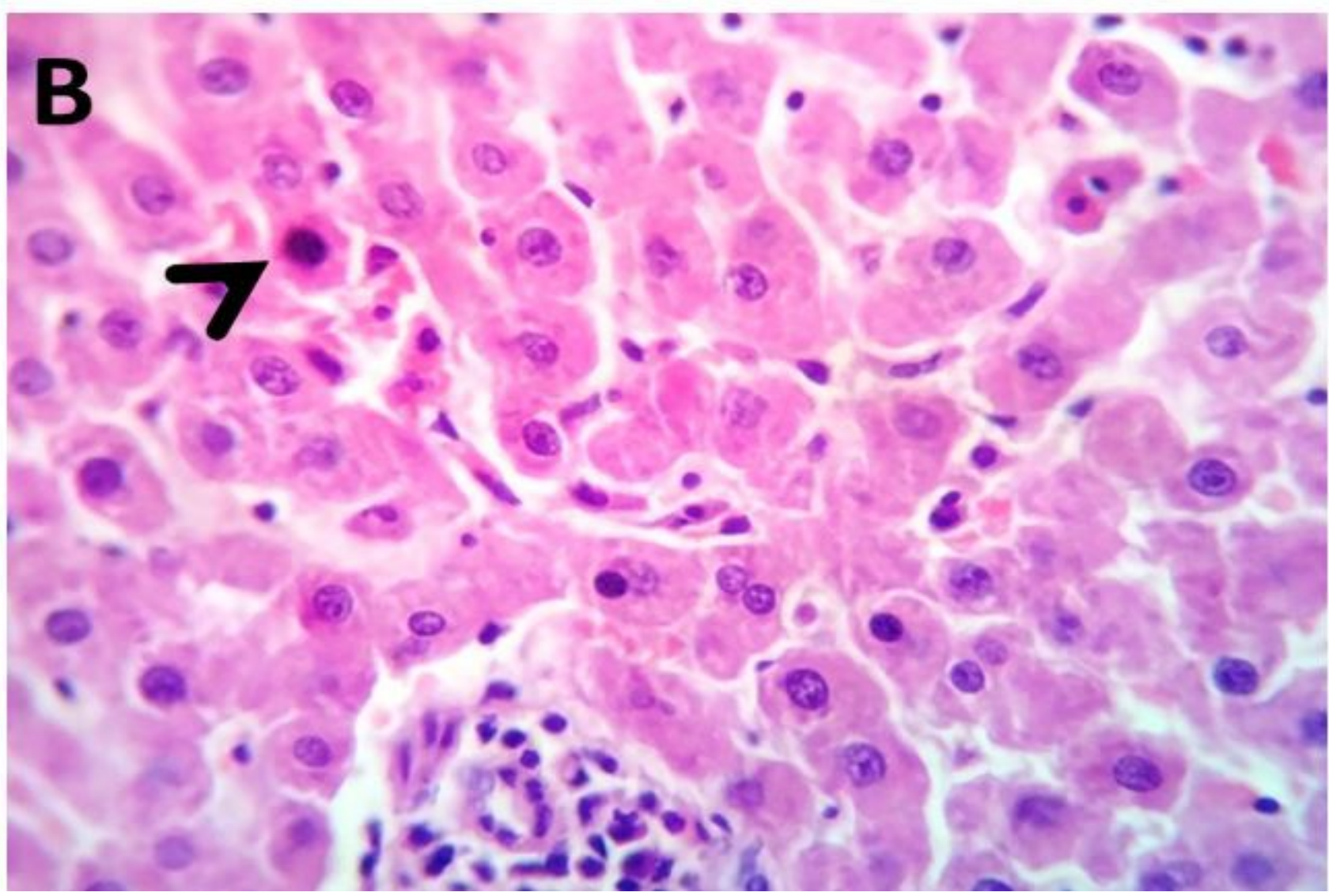

Figure 4 
Liver of obese rats fed on yoghurt supplemented green coffee extract.

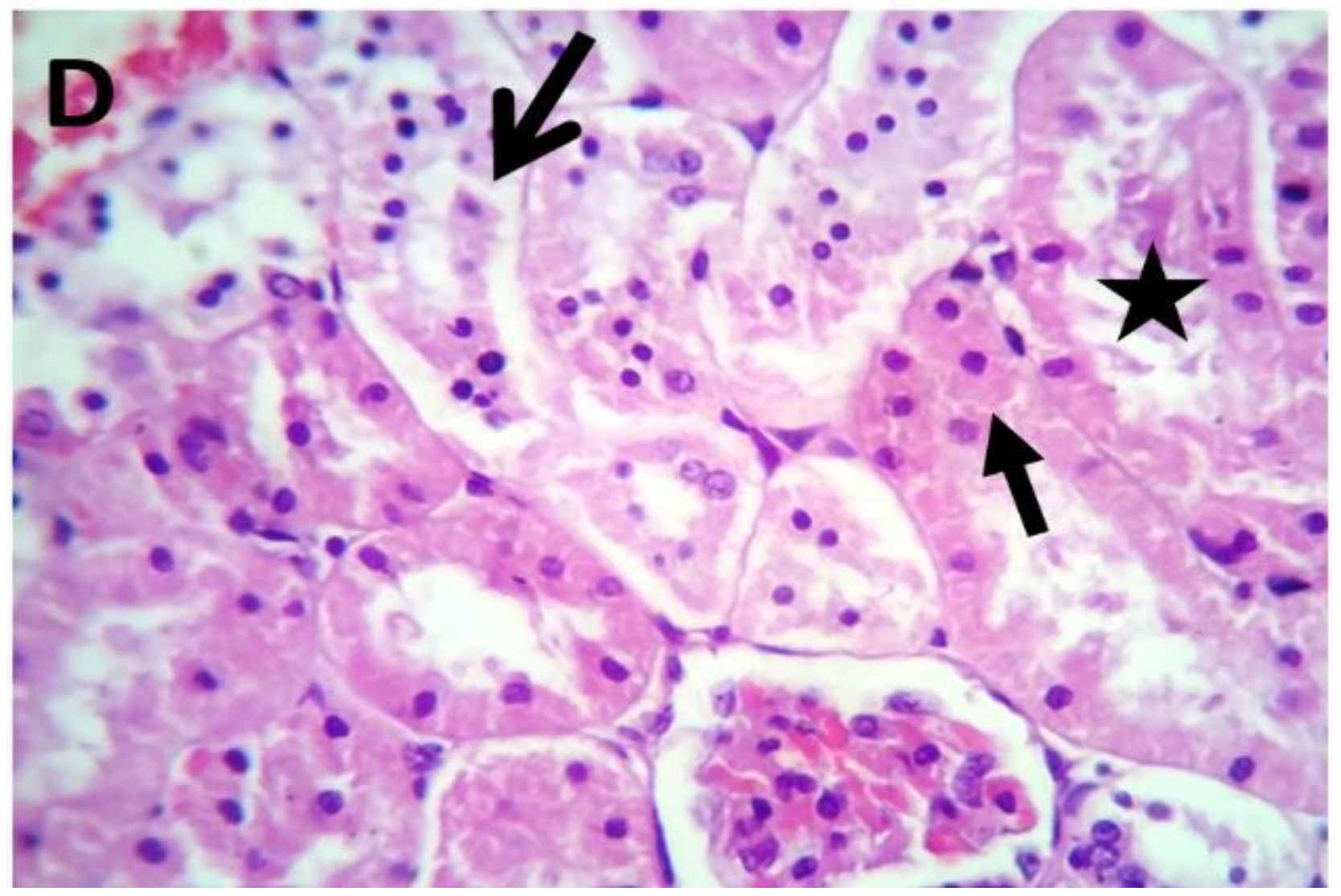

Figure 5

Kidney of obese rats fed on feeding normal (positive control group). 


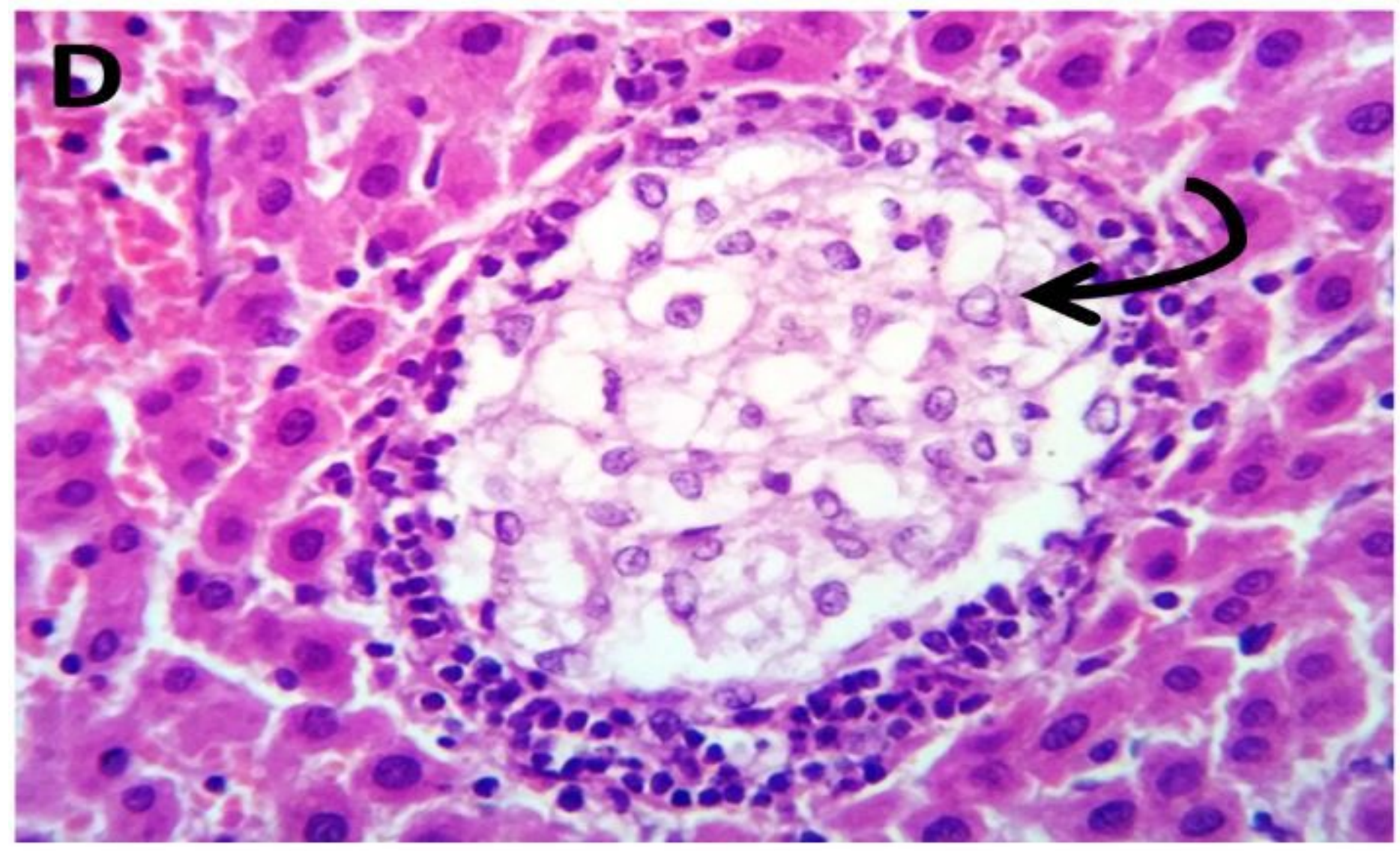

Figure 6

Kidney of obese rats fed on yoghurt without any additives. 


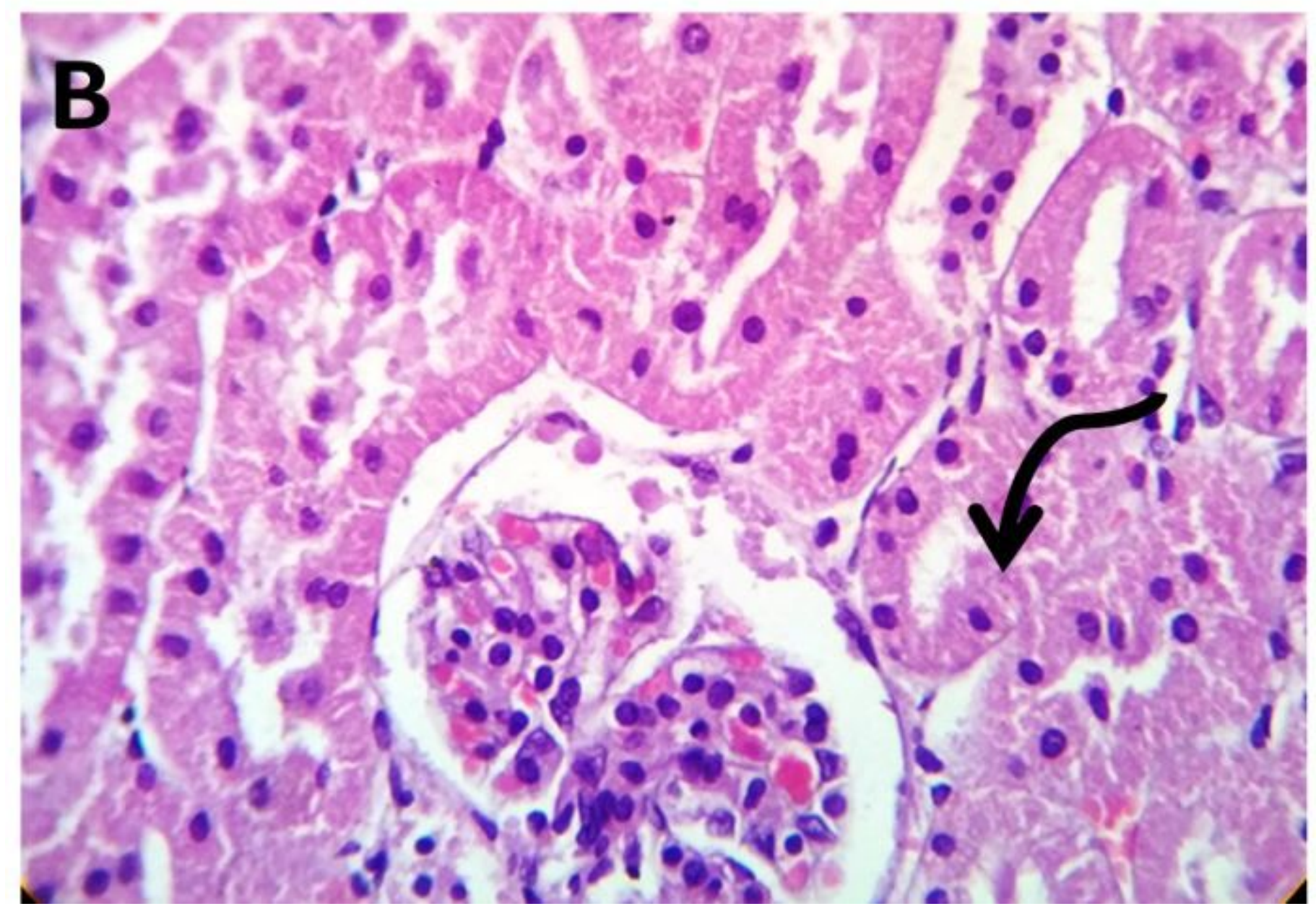

Figure 7

Kidney of obese rats fed on yoghurt supplemented green tea extract. 


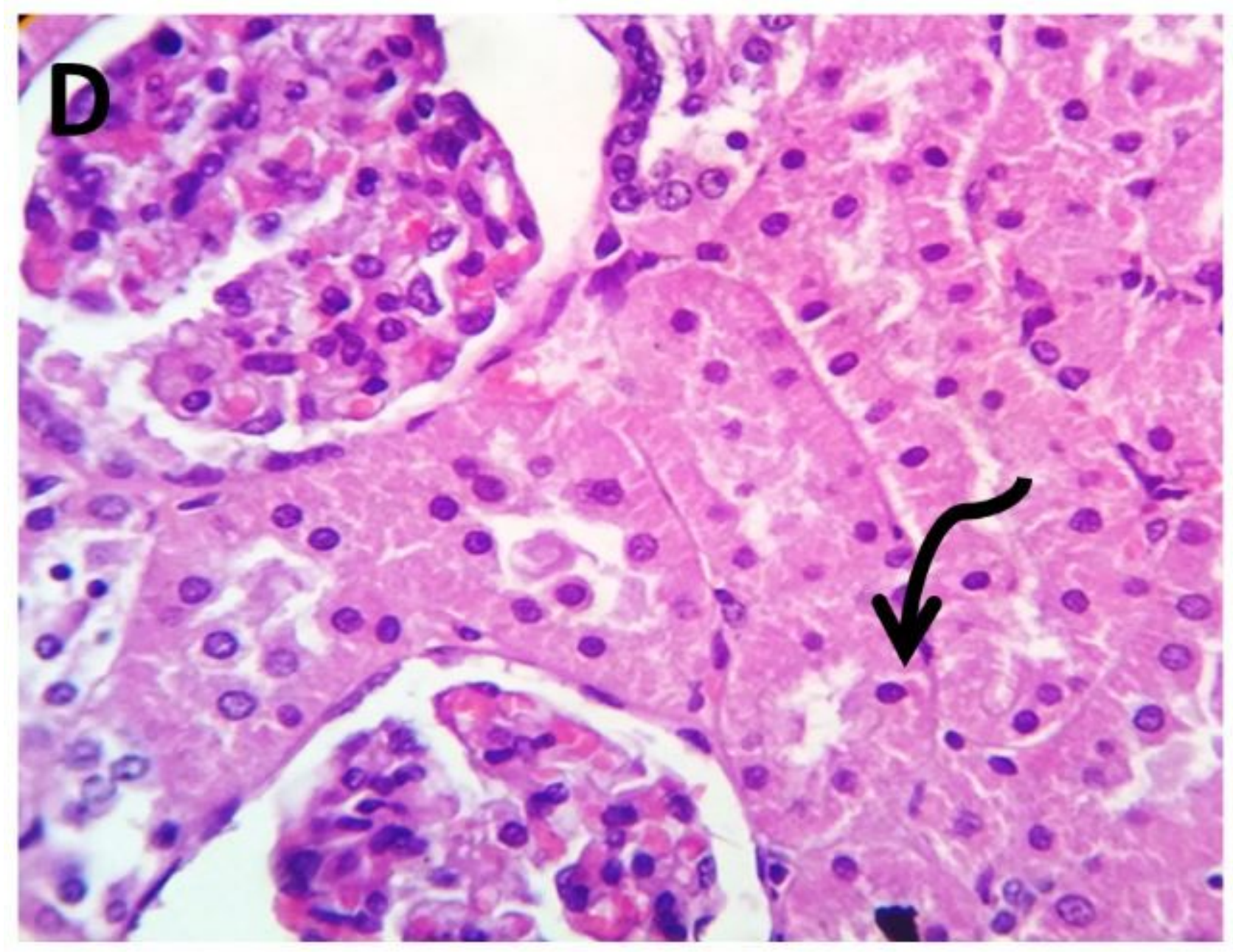

Figure 8

Kidney of obese rats fed on yoghurt supplemented green coffee extract. 


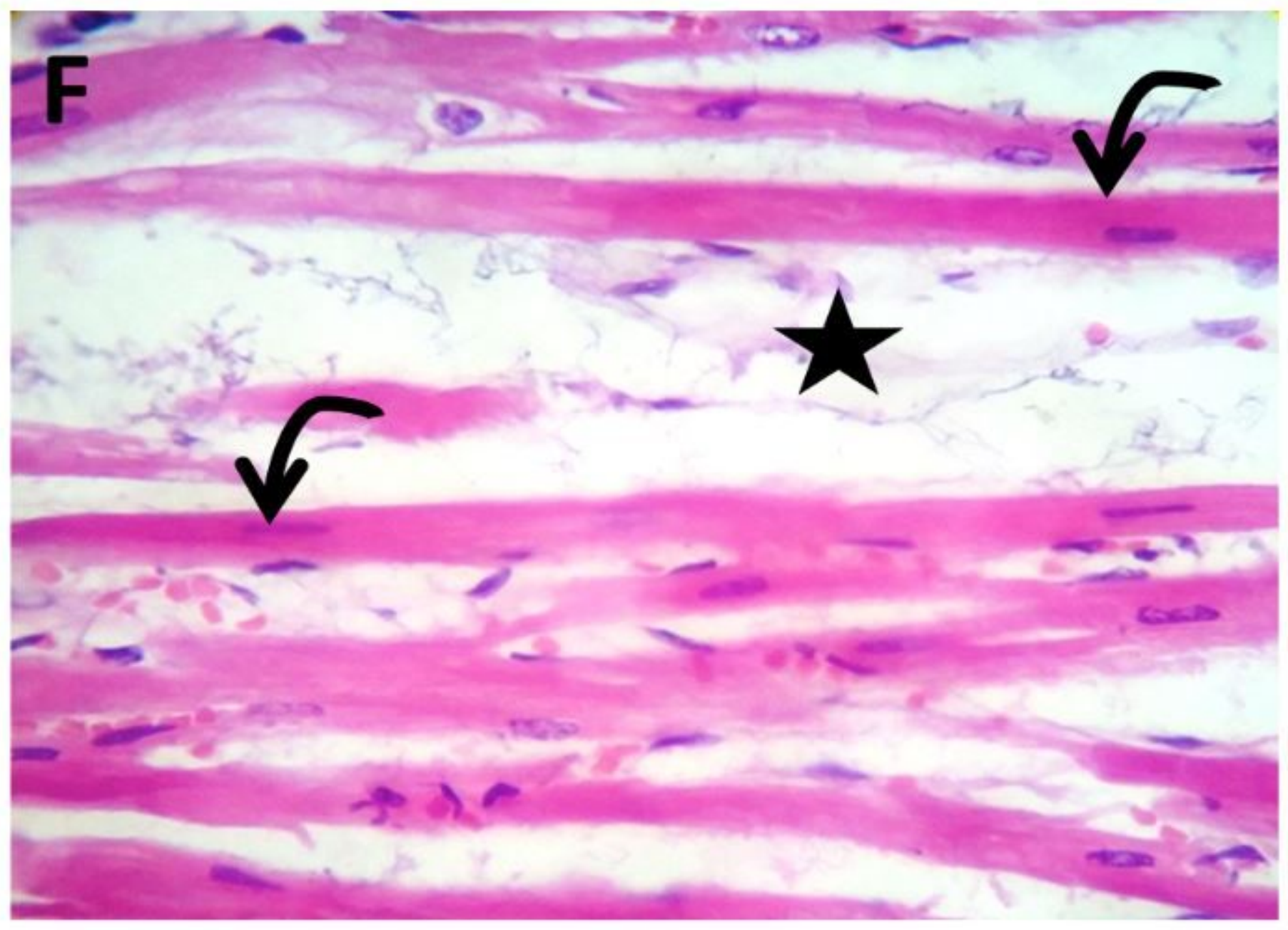

Figure 9

Heart of obese rats fed on feeding normal (positive control group). 


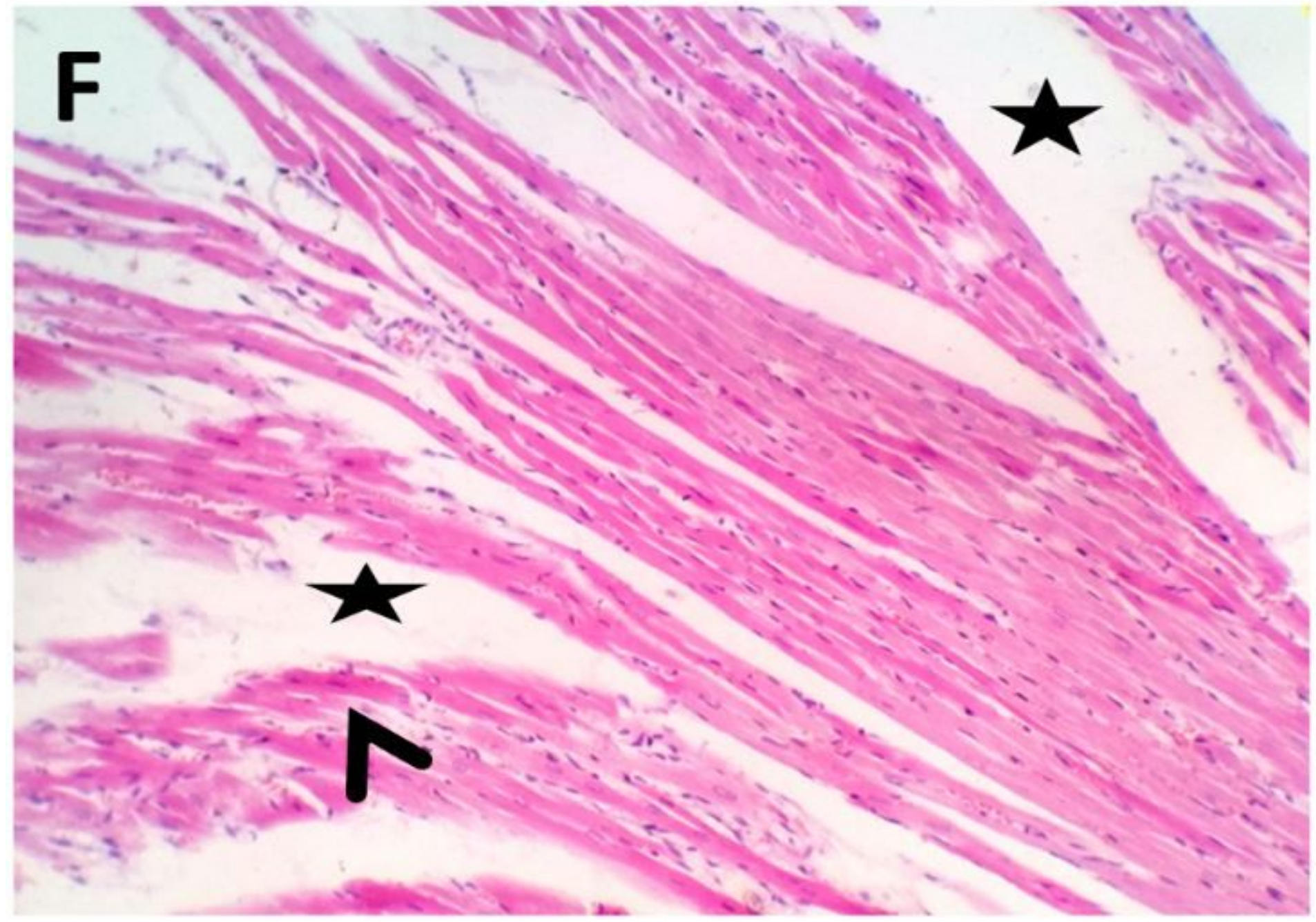

Figure 10

Heart of obese rats fed on yoghurt without any additives. 


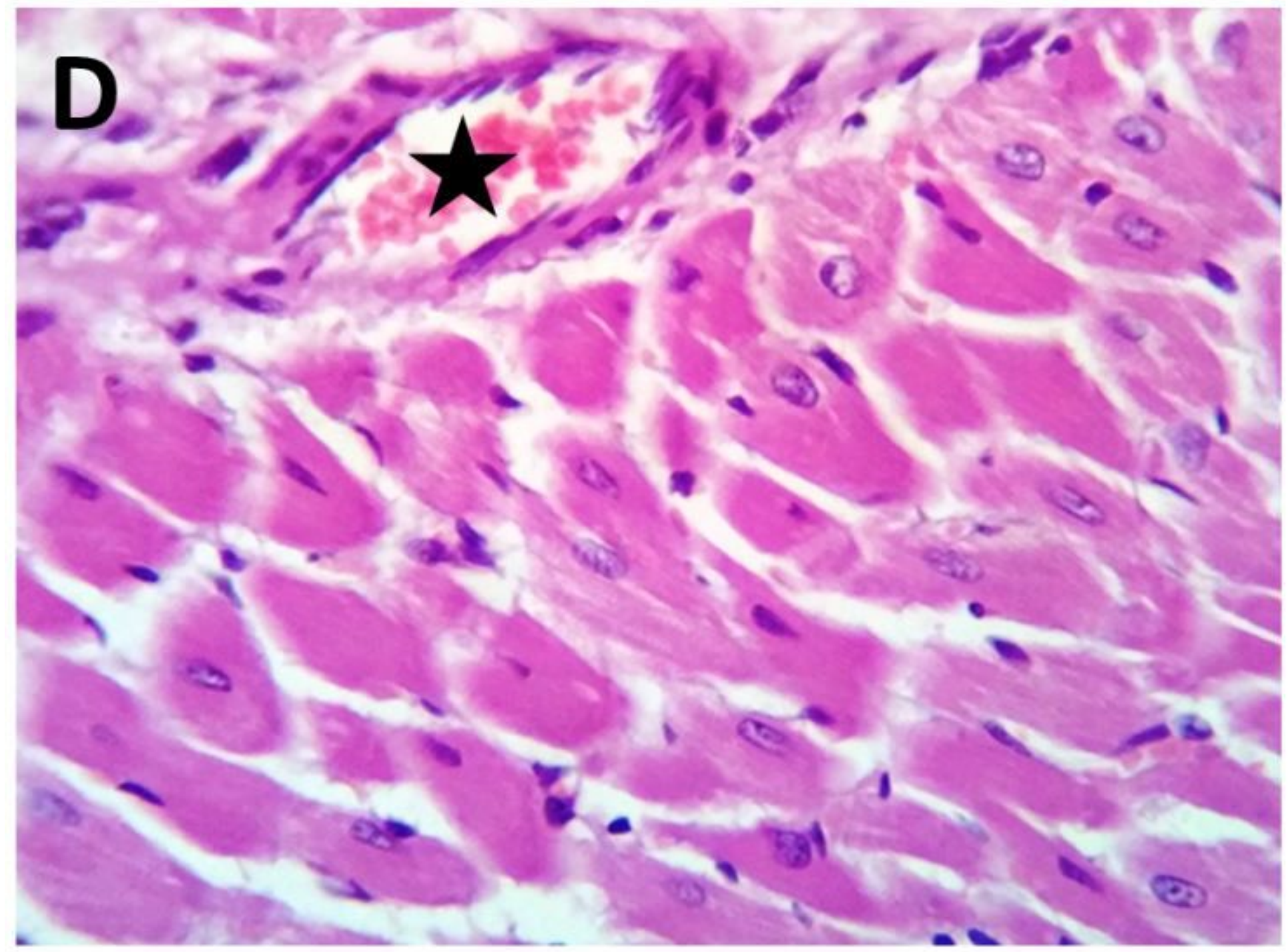

Figure 11

Heart of obese rats fed on yoghurt supplemented green tea extract. 


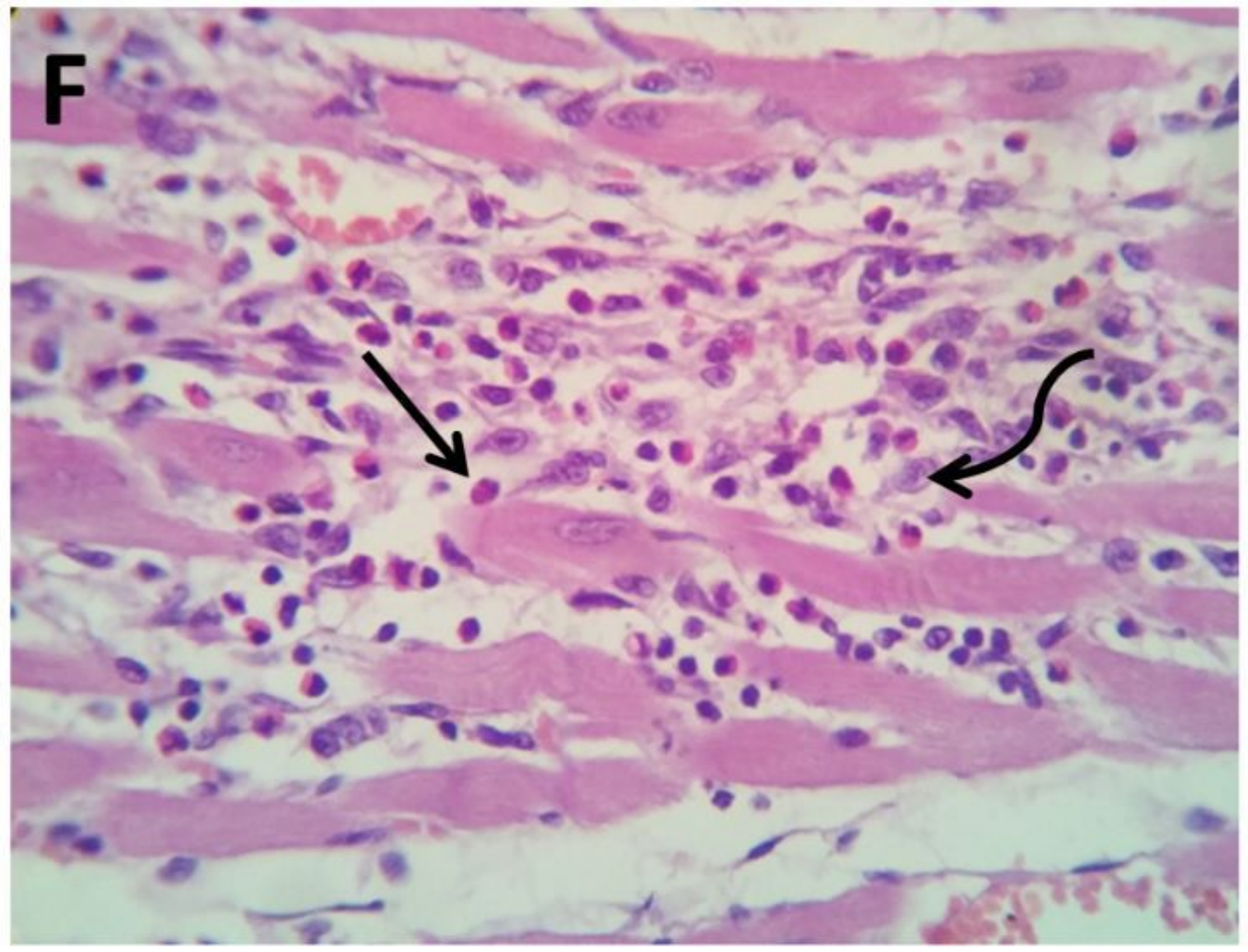

Figure 12

Heart of obese rats fed on yoghurt supplemented green coffee extract. 